\title{
ANALISIS DETERMINASI MINIMNYA MINAT DOSEN DALAM PENELITIAN
}

\author{
Fatkuroji \\ Dosen Fakultas Tarbiyah IAIN Walisongo Semarang
}

\begin{abstract}
Abstrak
Dosen adalah pendidik profesional dan ilmuwan dengan tugas utama mentransformasikan, mengembangkan, menyebarluaskan ilmu pengetahuan, teknologi, dan seni melalui pendidikan, penelitian, dan pengabdian kepada masyarakat. Kedudukan dosen sebagai tenaga profesional bertujuan untuk melaksanakan sistem pendidikan nasional dan mewujudkan tujuan pendidikan nasional, yaitu berkembangnya potensi peserta didik agar menjadi manusia yang beriman dan bertakwa kepada Tuhan Yang Maha Esa, berakhlak mulia, sehat, berilmu, cakap, kreatif, mandiri, serta menjadi warga negara yang demokratis dan bertanggung jawab.

Berkaitan dengan kedudukan dosen sebagai tenaga profesional dalam melaksanakan pendidikan, pengabdian kepada masyarakat serta meningkatkan dan mengembangkan kualifikasi akademik dan kompetensi secara berkelanjutan sejalan dengan perkembangan ilmu pengetahuan dan teknologi, maka dosen perlu membiasakan mengadakan penelitian.

Berbicara mengenai motivasi dosen dalam penelitian pada dasarnya merujuk pada seberapa besar ia menyukai penelitian, karena penelitian merupakan bagian yang penting bagi kehidupan dosen dalam dunia kampus, sehingga apa yang disampaikan adalah kebenaran berdasarkan data dan fakta nyata, bukan merupakan imajinasi atau ilusi pikiran dosen.

Perkembangan ilmu pengetahuan dan teknologi telah membawa perubahan di hampir semua aspek kehidupan manusia dimana berbagai permasalahan hanya dapat dipecahkan dengan upaya penguasaan dan peningkatan ilmu pengetahuan dan teknologi. Selain manfaat bagi kehidupan manusia di satu sisi perubahan tersebut juga telah membawa manusia ke dalam era persaingan global yang semakin ketat. Agar mampu berperan dalam persaingan global, maka dosen perlu terus mengembangkan dan meningkatkan kualitas dirinya. Oleh karena itu, peningkatan kualitas sumber daya dosen merupakan kenyataan yang harus dilakukan secara terencana, terarah, intensif, efektif dan efisien dalam proses pembangunan, kalau tidak ingin bangsa ini kalah bersaing dalam menjalani era globalisasi tersebut.

Gejala minimnya minat dosen dalam penelitian merupakan preseden buruk bagi dunia kampus pada umumnya dan mahasiswa pada kususnya. Jika dosen tidak
\end{abstract}


pernah melakukan sebuah penelitian maka dapat menghilangkan kompetensi fungsional yang dimilikinya.

Salah satu kompetensi yang harus dimiliki oleh dosen adalah mampu melakukan penelitian (Tri Darma Perguruan Tinggi). Hal ini karena pekerjaan dosen adalah sebuah profesi yang menuntut peningkatan pengetahuan dan keterampilan terus menerus sejalan dengan perkembangan ilmu pengetahuan dan teknologi serta pesatnya perubahan pendidikan dilapangan.

Atas dasar inilah maka dosen perlu melakukan penelitian agar yang disampaikan kepada mahasiswa bukan berdasarkan pada asumsi semata, intuisi, apalagi daya hayal, tetapi harus kebenaran yang logis, sistematis, ilmiah dan didukung oleh fakta. Berdasarkan diuraikan di atas, dapat difokuskan masalahnya adalah faktor apa saja yang menjadi determinasi rendahnya motivasi dosen dalam penelitian?

Kata Kunci: determinasi, minat dosen, penelitian

\section{A. Pendahuluan}

Undang-Undang Republik Indonesia nomor 14 tahun 2005 tentang guru dan dosen mengatakan bahwa untuk menjamin perluasan dan pemerataan akses, peningkatan mutu dan relevansi, serta tata pemerintahan yang baik dan akuntabilitas pendidikan yang mampu menghadapi tantangan sesuai dengan tuntutan perubahan kehidupan lokal, nasional, dan global perlu dilakukan pemberdayaan dan peningkatan mutu guru dan dosen secara terencana, terarah, dan berkesinambungan; bahwa guru dan dosen mempunyai fungsi, peran, dan kedudukan yang sangat strategis dalam pembangunan nasional dalam bidang pendidikan.

Dosen adalah pendidik profesional dan ilmuwan dengan tugas utama mentransformasikan, mengembangkan, menyebarluaskan ilmu pengetahuan, teknologi, dan seni melalui pendidikan, penelitian, dan pengabdian kepada masyarakat. Kedudukan dosen sebagai tenaga profesional bertujuan untuk melaksanakan sistem pendidikan nasional dan mewujudkan tujuan pendidikan nasional, yaitu berkembangnya potensi peserta didik agar menjadi manusia yang beriman dan bertakwa kepada Tuhan Yang Maha Esa, berakhlak mulia, sehat, berilmu, cakap, kreatif, mandiri, serta menjadi warga negara yang demokratis dan bertanggung jawab.

Berkaitan dengan kedudukan dosen sebagai tenaga profesional dalam melaksanakan pendidikan, pengabdian kepada masyarakat serta meningkatkan dan mengembangkan kualifikasi akademik dan kompetensi secara berkelanjutan sejalan dengan perkembangan ilmu pengetahuan dan teknologi, maka dosen perlu membiasakan mengadakan penelitian.

Berbicara mengenai motivasi dosen dalam penelitian pada dasarnya merujuk pada seberapa besar ia menyukai penelitian, karena penelitian merupakan bagian yang penting 
bagi kehidupan dosen dalam dunia kampus, sehingga apa yang disampaikan adalah kebenaran berdasarkan data dan fakta nyata, bukan merupakan imajinasi atau ilusi pikiran dosen.

Perkembangan ilmu pengetahuan dan teknologi telah membawa perubahan di hampir semua aspek kehidupan manusia dimana berbagai permasalahan hanya dapat dipecahkan dengan upaya penguasaan dan peningkatan ilmu pengetahuan dan teknologi. Selain manfaat bagi kehidupan manusia di satu sisi perubahan tersebut juga telah membawa manusia ke dalam era persaingan global yang semakin ketat. Agar mampu berperan dalam persaingan global, maka dosen perlu terus mengembangkan dan meningkatkan kualitas dirinya. Oleh karena itu, peningkatan kualitas sumber daya dosen merupakan kenyataan yang harus dilakukan secara terencana, terarah, intensif, efektif dan efisien dalam proses pembangunan, kalau tidak ingin bangsa ini kalah bersaing dalam menjalani era globalisasi tersebut.

Berbicara mengenai kualitas sumber daya manusia, pendidikan memegang peran yang sangat penting dalam proses peningkatan kualitas sumber daya manusia. Peningkatan kualitas pendidikan merupakan suatu proses yang terintegrasi dengan proses peningkatan kualitas sumber daya manusia itu sendiri. Menyadari pentingnya proses peningkatan kualitas sumber daya manusia, maka pemerintah bersama kalangan swasta sama-sama telah dan terus berupaya mewujudkan amanat tersebut melalui berbagai usaha pembangunan pendidikan yang lebih berkualitas antara lain melalui pelatihan, pengembangan sumberdaya manusia khusunya bagi dosen untuk mengadakan penelitian, serta kesempatan studi lanjut. Berkaitan dengan penelitian, pada kenyataannya motivasi mengadakan penelitian yang dilakukan oleh dosen masih cukup rendah.

Gejala minimnya minat dosen dalam penelitian merupakan preseden buruk bagi dunia kampus pada umumnya dan mahasiswa pada kususnya. Jika dosen tidak pernah melakukan sebuah penelitian maka dapat menghilangkan kompetensi fungsional yang dimilikinya.

Salah satu kompetensi yang harus dimiliki oleh dosen adalah mampu melakukan penelitian (Tri Darma Perguruan Tinggi). Hal ini karena pekerjaan dosen adalah sebuah profesi yang menuntut peningkatan pengetahuan dan keterampilan terus menerus sejalan dengan perkembangan ilmu pengetahuan dan teknologi serta pesatnya perubahan pendidikan dilapangan.

Kita ketahui bahwa pendidikan dan bidang-bidang kehidupan lain yang terjadi di luar sistem pendidikan saling mempengaruhi. Dalam rangka memperjelas kaitan antara pendidikan dengan bidang-bidang kehidupan yang ada di luar sistem pendidikan, ada beberapa faktor yang terjadi di luar sistem pendidikan yang perlu dibahas agar tampak berkaitan fungsionalnya dengan sistem pendidikan. Faktor tersebut meliputi ketenagakerjaan, sosial, budaya, politik dan lain-lainnya. Pada dasarnya pendidikan memiliki fungsi yang hakiki dalam mempersiapkan sumber daya manusia yang akan menjadi aktor-aktor 
dalam menjalankan fungsi dari berbagai bidang kehidupan yang bersangkutan. Berkaitan dengan fungsi tersebut, berjalannya sistem pendidikan tidak boleh lepas dari perubahan yang terjadi dalam berbagai bidang kehidupan tersebut.

Berdasarkan hal di atas, tantangan yang dihadapi oleh pendidikan tidak semata-mata datang dari sistem pendidikan secara internal atau tantangan yang berasal dari luar sistem pendidikan. Tantangan ekternal dari sistem pendidikan seharusnya merupakan sumber aspirasi yang paling utama dalam melakukan perubahan dan pembaharuan sistem pendidikan itu sendiri secara internal. Dengan demikian pendidikan tidak akan terus mendapat tudingan building its own island seperti halnya kritik-kritik yang selalu terlontar dari berbagai pihak yang menaruh perhatian positip terhadap sistem pendidikan nasional. (H.A. Tilaar, 1999: 4)

Dengan melakukan kajian terhadap keadaan dan permasalahan mengenai bidangbidang kehidupan lain di luar pendidikan, beberapa permasalahan dan tantangan dalam pembangunan sistem pendidikan akan muncul kepermukaan. Tantangan masa depan bagi sistem pendidikan di kampus tidak semata-mata menyangkut bagaimana meningkatkan mutu dan efesiensi pendidikan secara internal, tetapi juga menyangkut bagaimana meningkatkan kesesuaian pendidikan dengan bidang-bidang kehidupan lain.

Melihat hal tersebut setiap bidang pekerjaan selalu dihadapkan pada permasalahan yang selalu berkembang, baik berupa fenomena yang mengundang tanda tanya, maupun kesenjangan antara yang diharapkan dengan kenyataan. Permasalahan tersebut menuntut jawaban dan solusi yang dapat dipertanggung jawabkan.

Kedudukan dosen sebagai agen transformasi ilmu pengetahuan kepada para mahasiswa dan mahasiswi, mengharuskannya memiliki kesiapan memberikan solusi bagi permasalahan yang mereka hadapi. Dalam penyampaian materi dosen dapat saja mengandalkan pengalaman, baik dirinya sendiri maupun orang lain, mengambil teori dari buku-buku, atau bahkan mengandalkan intuisi. Hal ini tentu tidak selamanya memuaskan, karena yang dituntut darinya adalah professional judgement yang dapat dijadikan acuan.

Penelitian merupakan suatu bentuk kegiatan ilmiah untuk mendapatkan pengetahuan atau kebenaran. Ada dua teori kebenaran pengetahuan, yaitu teori koherensi dan korespondensi. Teori koherensi beranggapan bahwa suatu pernyataan dikatakan benar apabila sesuai dan tidak bertentangan dengan pernyataan sebelumnya. Aturan yang dipakai adalah logika berpikir atau berpikir logi. Sementara itu teori korenspondensi berasumsi bahwa sebuah pernyataan dipandang benar apabila sesuai dengan kenyataan (fakta atau realita). Untuk menemukan kebenaran yang logis dan didukung oleh fakta, maka harus dilakukan penelitian terlebih dahulu. ${ }^{1}$ Inilah hakikat penelitian sebagai kegiatan ilmiah atau sebagai proses the acquisition of knowledge.

1 Sukardi, Metodologi Penelitian Pendidikan (Kompetensi dan Praktiknya), (akarta: Bumi Aksara, 2003),
hlm. 34 
Dalam perkembangannya, terdapat beragam pendekatan, jenis serta metode penelitian sesuai dengan paradigma keilmuan serta realitas gejala yang hendak diungkap. Untuk dapat memilih pendekatan dan/atau metode yang tepat, seseorang dituntut memahami substansi keilmuan/bidang kajian dan metodologi penelitian. Hal ini tentu sangat dibutuhkan oleh dosen, yang dalam tugasnya selalu dihadapkan pada persoalan pendidikan baik pada kawasan institusional maupun teknis operasional.

Atas dasar inilah maka dosen perlu melakukan penelitian agar yang disampaikan kepada mahasiswa bukan berdasarkan pada asumsi semata, intuisi, apalagi daya hayal, tetapi harus kebenaran yang logis, sistematis, ilmiah dan didukung oleh fakta. Berdasarkan diuraikan di atas, dapat di fokuskan masalahnya adalah faktor apa saja yang menjadi determinasi rendahnya motivasi dosen dalam penelitian?

\section{B. Penelitian}

Penelitian digambarkan sebagai suatu kegiatan untuk menyelesaikan suatu teka-teki. Bagi seorang peneliti, teka-teki merupakan masalah-masalah yang dapat diatasi atau diselesaikan melalui penalaran. Setiap saat kita melakukan penalaran dengan tingkat keberhasilan yang berbeda dan mengkomunikasikan pengertian itu dalam bahasa seharihari, atau dalam kasus-kasus khusus, dalam bentuk logis dan simbolis. Penyampaian pengertian itu melalui dua cara yaitu eksposisi atau argumentasi. Eksposisi terdiri dari pernyataan-pernyataan deskriptif yang sekadarnya saja dan mempunyai alasan-alasan. Argumentasi memungkinkan kita untuk menjelaskan, mengartikan, membela, menantang, dan menjajaki pengertian yang disampaikan. Hasil penelitian harus dijelaskan dengan argumen yang dapat diterima. Ada dua jenis bentuk argumen yang sangat penting dalam penelitian yaitu deduksi (deduction) dan induksi (induction). ${ }^{2}$

Deduksi merupakan proses pengambilan kesimpulan sebagai akibat dari alasanalasan yang diajukan berdasarkan hasil analisis data. Proses pengambilan kesimpulan dengan cara deduksi didasari oleh alasan-alasan yang benar dan valid. Proses pengambilan kesimpulan berdasarkan alasan-alasan yang valid atau dengan menguji hipotesis dengan menggunakan data empiris disebut proses deduksi (deduction) dan metodenya disebut metode deduktif (deductive method) dan penelitiannya disebut penelitian deduktif (deductive research). Proses deduksi selalu digunakan pada penelitian yang menggunakan pendekatan kuantitatif (scientific).

Deduksi dikatakan tepat jika premis (alasan) dan konklusi benar dan sahih, hal ini berarti: (1) Alasan (premis) yang diberikan untuk kesimpulan harus sesuai dengan kenyataan (benar), (2) kesimpulan harus diambil dari alasan-alasannya (sahih).

2 Lincoln, Y.S., \& Guba, E.G., Naturalistic Inquiry, (Beverly Hill: Sage Publication Inc., 1985), hlm. 89-115 
Induksi didefinisikan sebagai proses pengambilan kesimpulan (atau pembentukan hipotesis) yang didasarkan pada satu atau dua fakta atau bukti-bukti. Pendekatan induksi sangat berbeda dengan deduksi. Tidak ada hubungan yang kuat antara alasan dan konklusi. Proses pembentukan hipotesis dan pengambilan kesimpulan berdasarkan data yang diobservasi dan dikumpulkan terlebih dahulu disebut proses induksi (induction process) dan metodenya disebut metode induktif (inductive method) dan penelitiannya disebut penelitian induktif (inductive research). Dengan demikian pendekatan induksi mengumpulkan data terlebih dahulu baru hipotesis dibuat jika diinginkan atau konklusi langsung diambil jika hipotesis tidak digunakan. Proses induksi selalu digunakan pada penelitian dengan pendekatan kualitatif (naturalis).

\section{Pengertian Penelitian}

Pada hakikatnya penelitian memberikan pengetahuan dan keterampilan yang diperlukan untuk mengatasi masalah serta menghadapi tantangan lingkungan di mana pengambilan keputusan harus dilakukan dengan cepat. Keputusan yang diambil akan bersifat lebih ilmiah jika dilakukan melalui proses penelitian. Untuk lebih memahami apa itu penelitian, di bawah ini diuraikan pengertian dari penelitian yang dikemukakan para tokoh yang tahu tentang penelitian, di antaranya adalah:

Penelitian tidak lain adalah art end science guna mencari jawaban terhadap suatu permasalahan (Yoseph dan Yoseph, 1979), dengan diartikan seni dan ilmiah maka penelitian juga akan memberikan ruang-ruang yang akan mengakomodasi adanya perbedaan apa yang dimaksud dengan penelitian.

Penelitian dapat pula diartikan sebagai cara pengamatan atau inquiry dan mempunyai tujuan untuk mencari jawaban permasalahan atau proses penemuan, baik itu discovery maupun invations. Discovery diartikan hasil temuan yang memang sebetulnya sudah ada, sedangkan invations dapat diartikan sebagai penemuan hasil penelitian yang betul-betul baru dengan dukungan fakta. ${ }^{3}$

Sementara Ibrahim (1989) mengatakan invention adalah penemuan sesuatu yang benar-benar baru artinya hasil karya manuasia. Sedangkan discovery adalah penemuan sesuatu yang sebenarnya telah ada sebelumnya. Dengan demikian, penelitian yang benarbenar baru dapat diartikan usaha menemukan sesuatu yang baru dengan jalan melakukan kegiatan (usaha) invention dan discovery. Dalam kaitan ini Ibrahim mengatakan bahwa invention dan discovery adalah penemuan yang dapat berupa sesuatu ide, kejadian, metode yang diamati sebagai sesuatu hal yang baru bagi seseorang atau sekelompok orang (masyarakat) (Subandiyah 1992: 80)

\footnotetext{
${ }^{3}$ Sukardi, Metodologi Penelitian Pendidikan..., hlm. 3
} 
Proses dan tahapan perubahan itu ada kaitannya dengan masalah pengembangan (development), penyebaran (diffusion), diseminasi (dissemination), perencanaan (planning), adopsi (adoption), penerapan (implementation) dan evaluasi (evaluation) (Subandiyah 1992: 77)

Lebih lanjut Sukardi mengatakan penelitian adalah merupakan proses ilmiah yang mencakup sifat formal dan intensif. Karakter formal dan intensif karena mereka terikat dengan aturan, urutan, maupun cara penyajiannya agar memperoleh hasil yang diakui dan bermanfaat bagi kehidupan manusia. Intensif dengan menerapkan ketelitian dan ketepatan dalam melakukan proses penelitian agar memperoleh hasil yang dapat di pertanggung jawabkan, memecahkan problem melalui hubunagn sebab dan akibat, dapat diulang kembali dengan cara yang sama dan hasil yang sama.

Penelitian adalah investigasi yang sistematis, terkontrol, empiris dan kritis dari suatu proposisi hipotesis mengenai hubungan tertentu antarfenomena. Penelitian merupakan refleksi dari keinginan untuk mengetahui sesuatu berupa fakta-fakta atau fenomena alam. Perhatian atau pengamatan awal terhadap fakta atau fenomena merupakan awal dari kegiatan penelitian yang menimbulkan suatu pertanyaan atau masalah (Indriantoro \& Supomo, 1999: 16).

Lebih lanjut Indriantoro \& Supomo mengatakan penelitian pada dasarnya merupakan penelitian yang sistematis dengan tujuan untuk memperoleh pengetahuan yang bemanfaat untuk menjawab pertanyaan atau memecahkan masalah dalam kehidupan sehari-hari (Indriantoro \& Supomo, 1999: 16).

Berdasarkan beberapa definisi penelitian yang diungkapkan di atas dapat diambil kesimpulan bahwa penelitian merupakan suatu proses pengumpulan, pencatatan, dan analisis data yang sistematis untuk pengambilan kesimpulan yang objektif dalam rangka membantu dalam pembuatan keputusan-keputusan.

\section{Hakikat Penelitian}

Penelitian sebagai upaya untuk memperoleh kebenaran harus didasari oleh proses berpikir ilmiah yang dituangkan dalam metode ilmiah. Metode ilmiah adalah kerangka landasan bagi terciptanya pengetahuan ilmiah. Penelitian yang dilakukan menggunakan metode ilmiah mengandung dua unsur penting yakni pengamatan (observation) dan penalaran (reasoning) ${ }^{4}$

Metode ilmiah didasari oleh pemikiran bahwa apabila suatu pernyataan ingin diterima sebagai suatu kebenaran maka pernyataan tersebut harus dapat diverifikasi atau diuji kebenarannya secara empirik (berdasarkan fakta).

${ }^{4}$ Singgih Faisal, Penelitian Kualitatif, (Malang: YA3, 1990), hlm. 65 
Rasa ingin tahu merupakan salah satu sifat dasar yang dimiliki manusia. Sifat tersebut akan mendorong manusia bertanya untuk mendapatkan pengetahuan. Setiap manusia yang berakal sehat sudah pasti memiliki pengetahuan, baik berupa fakta, konsep, prinsip, maupun prosedur tentang suatu objek.

Pengetahuan dapat dimiliki berkat adanya pengalaman atau melalui interaksi antara manusia dengan lingkungannya. Secara universal, terdapat tiga jenis pengetahuan yang selama ini mendasari kehidupan manusia yaitu: (1) logika yang dapat membedakan antara benar dan salah; (2) etika yang dapat membedakan antara baik dan buruk; serta (3) estetika yang dapat membedakan antara indah dan jelek (Suria sumantri, 1990: 65). Kepekaan indra yang dimiliki, merupakan modal dasar dalam memperoleh pengetahuan tersebut.

Salah satu wujud pengetahuan yang dimiliki manusia adalah pengetahuan ilmiah yang lazim dikatakan sebagai "ilmu". Ilmu adalah bagian pengetahuan, namun tidak semua pengetahuan dapat dikatakan ilmu. Ilmu adalah pengetahuan yang didasari oleh dua teori kebenaran yaitu koherensi dan korespondensi. 5

Koherensi menyatakan bahwa sesuatu pernyataan dikatakan benar jika pernyataan tersebut konsisten dengan pernyataan sebelumnya. Koherensi dalam pengetahuan diperoleh melalui pendekatan logis atau berpikir secara rasional. Korespondensi menyatakan bahwa suatu pernyataan dikatakan benar jika pernyataan tersebut didasarkan atas fakta atau realita. Koherensi dalam pengetahuan diperoleh melalui pendekatan empirik atau bertolak dari fakta. ${ }^{6}$ Dengan demikian, kebenaran ilmu harus dapat dideskripsikan secara rasional dan dibuktikan secara empirik

Koherensi dan korespondensi mendasari bagaimana ilmu diperoleh telah melahirkan cara mendapatkan kebenaran ilmiah. Proses untuk mendapatkan ilmu agar memiliki nilai kebenaran harus dilandasai oleh cara berpikir yang rasional berdasarkan logika dan berpikir empiris berdasarkan fakta. Salah satu cara untuk mendapatkan ilmu adalah melalui penelitian. ${ }^{7}$

Banyak definisi tentang penelitian tergantung sudut pandang masing-masing Penelitian dapat didefinisikan sebagai upaya mencari jawaban yang benar atas suatu masalah berdasarkan logika dan didukung oleh fakta empirik (Suryabrata, 1998: 72).

Dapat pula dikatakan bahwa penelitian adalah kegiatan yang dilakukan secara sistematis melalui proses pengumpulan data, pengolah data, serta menarik kesimpulan berdasarkan data menggunakan metode dan teknik tertentu (Poerwandari, 1998: 85).

${ }^{5}$ Sudjana, Nana, Tuntunan Penyusunan Karya Ilmiah, (Bandung: Sinar Baru Algesindo, 2001), hlm. 45

6 Danim, Sudarwan, Metode Penelitian untuk Ilmu-Ilmu Perilaku, (Jakarta: Bumi Aksara, 2000), hlm. 102

${ }^{7}$ Ibid., hlm. 112 
Pengertian tersebut di atas menyiratkan bahwa penelitian adalah langkah sistematis dalam upaya memecahkan masalah. Penelitian merupakan penelaahan terkendali yang mengandung dua hal pokok yaitu logika berpikir dan data atau informasi yang dikumpulkan secara empiris. ${ }^{8}$

Logika berpikir tampak dalam langkah-langkah sistematis mulai dari pengumpulan, pengolahan, analisis, penafsiran dan pengujian data sampai diperolehnya suatu kesimpulan. Informasi dikatakan empiris jika sumber data menggambarkan fakta yang terjadi bukan sekedar pemikiran atau rekayasa peneliti. Penelitian menggabungkan cara berpikir rasional yang didasari oleh logika/penalaran dan cara berpikir empiris yang didasari oleh fakta/ realita.

Penelitian sebagai upaya untuk memperoleh kebenaran harus didasari oleh proses berpikir ilmiah yang dituangkan dalam metode ilmiah. Metode ilmiah adalah kerangka landasan bagi terciptanya pengetahuan ilmiah. Penelitian yang dilakukan menggunakan metode ilmiah mengandung dua unsur penting yakni pengamatan (observation) dan penalaran (reasoning). Metode ilmiah didasari oleh pemikiran bahwa apabila suatu pernyataan ingin diterima sebagai suatu kebenaran maka pernyataan tersebut harus dapat diverifikasi atau diuji kebenarannya secara empirik (berdasarkan fakta).

Terdapat empat langkah pokok metode ilmiah yang akan mendasari langkahlangkah penelitian yaitu:

a. Merumuskan masalah; mengajukan pertanyaan untuk dicari jawabannya. Tanpa adanya masalah tidak akan terjadi penelitian, karena penelitian dilakukan untuk memecahkan masalah. Rumusan masalah penelitian pada umumnya diajukan dalam bentuk pertanyaan

b. Mengajukan hipotesis; mengemukakan jawaban sementara (masih bersifat dugaan) atas pertanyaan yang diajukan sebelumnya. Hipotesis penelitian dapat diperoleh dengan mengkaji berbagai teoriberkaitan dengan bidang ilmu yang dijadikan dasar dalam perumusan masalah. Peneliti menelusuri berbagai konsep, prinsip, generalisasi dari sejumlah literatur, jurnal dan sumber lain berkaitan dengan masalah yang diteliti. Kajian terhadap teori merupakan dasar dalam merumuskan kerangka berpikir sehingga dapat diajukan hipotesis sebagai alternatif jawaban atas masalah

c. Verifikasi data; mengumpulkan data secara empiris kemudian mengolah dan menganalisis data untuk menguji kebenaran hipotesis. Jenis data yang diperlukan diarahkan oleh makna yang tersirat dalam rumusan hipotesis. Data empiris yang diperlukan adalah data yang dapat digunakan untuk menguji hipotesis. Dalam hal ini, peneliti harus menentukan jenis data, dari mana data diperoleh, serta teknik untuk memperoleh data. Data yang terkumpul diolah dan dianalisis dengan cara-

8 Sudjana, N. dan Ibrahim, R., Penelitian dan Penilaian Pendidikan, (Bandung: Sinar Baru Algesindo, 2001), hlm. 97 
cara tertentu yang memenuhi kesahihan dan keterandalan sebagai bahan untuk menguji hipotesis.

d. Menarik kesimpulan; menentukan jawaban-jawaban definitif atas setiap pertanyaan yang diajukan (menerima atau menolak hipotesis). Hasil uji hipotesis adalah temuan penelitian atau hasil penelitian. Temuan penelitian dibahas dan disintesiskan kemudian disimpulkan. Kesimpulan merupakan adalah jawaban atas rumusan masalah penelitian yang disusun dalam bentuk proposisi atau pernyataan yang telah teruji kebenarannya. ${ }^{9}$

Dengan mengikuti langkah-langkah di atas, penelitian ilmiah merupakan kegiatan yang dilaksanakan untuk mengkaji dan memecahkan suatu masalah menggunakan prosedur sistematis berlandaskan data empirik. Berdasarkan proses tersebut di atas, mulai dari langkah kajian teori sampai pada perumusan hipotesis termasuk berpikir rasional atau berpikir deduktif. Sedangkan dari verifikasi data sampai pada generalisasi merupakan proses berpikir induktif. Proses tersebut adala wujud dari proses berpikir ilmiah. Itulah sebabnya penelitian dikatakan sebagai operasionalisasi metode ilmiah.

Untuk mendapatkan kebenaran ilmiah, penelitian harus mengandung unsur keilmuan dalam aktivitasnya. Penelitian yang dilaksanakan secara ilmiah berarti kegiatan penelitian didasarkan pada karakeristik keilmuan yaitu: (1) Rasional: penyelidikan ilmiah adalah sesuatu yang masuk akal dan terjangkau oleh penalaran manusia, (2) Empiris: menggunakan cara-cara tertentu yang dapat diamati orang lain dengan menggunakan panca indera manusia, (3) Sistematis: menggunakan proses dengan langkah-langkah tertentu yang bersifat logis.

Penelitian dikatakan tidak ilmiah jika tidak menggunakan penalaran logis, tetapi menggunakan prinsip kebetulan, coba-coba, spekulasi. Cara-cara seperti ini tidak tepat digunakan untuk pengembangan suatu profesi ataupun keilmuan tertentu. Suatu penelitian dikatakan baik (dalam arti ilmiah) jika mengikuti cara-cara yang telah ditentukan serta dilaksanakan dengan adanya unsur kesengajaan bukan secara kebetulan.

Dalam keseharian sering ditemukan konsep-konsep yang kurang tepat dalam memaknai penelitian antara lain:

a. Penelitian bukan sekedar kegiatan mengumpulkan data atau informasi. Misalnya, seseorang bermaksud mengadakan penelitian tentang latar belakang pendidikan orang tua mahasiswa di kampusnya. Kemudian seseorang tersebut belum dapat dikatakan melakukan penelitian tetapi hanya sekedar mengumpulkan data atau informasi saja. Pengumpulan data hanya merupakan salah satu bagian kegiatan dari rangkaian proses penelitian. Langkah berikutnya yang harus dilakukan adalah hlm. 89

9 Sarwono \& Jonathan, Penuntun Penelitian Praktis, (Bandung: Universitas Kristen Maranatha, 1995), 
menganalisis data. Data yang telah diperolehnya dapat digunakan misalnya untuk meneliti pengaruh latar belakang pendidikan orang tua terhadap prestasi belajar.

b. Penelitian bukan hanya sekedar memindahkan fakta dari suatu tempat ke tempat lain. Misalnya seorang dosen telah berhasil mengumpulkan banyak data/infromasi tentang implementasi MBS di sekolah binaannya dan menyusunnya dalam sebuah laporan. Kegiatan yang dilakukan dosen tersebut bukanlah suatu penelitian. Laporan yang dihasilkannya juga bukan laporan penelitian. Kegiatan dimaksud akan menjadi suatu penelitian ketika dosen yang bersangkutan melakukan analisis data lebih lanjut sehingga diperoleh suatu kesimpulan. Misalnya: (1) faktor-faktor yang mempengaruhi keberhasilan implementasi MBS; atau (2) faktor-faktor penghambat implementasi MBS serta upaya mengatasinya.

Uraian di atas memperlihatkan bahwa penelitian adalah penyaluran rasa ingin tahu manusia terhadap sesuatu/masalah dengan melakukan tindakan tertentu (misalnya memeriksa, menelaah, mempelajari dengan cermat/sungguh-sungguh) sehingga diperoleh suatu temuan berupa kebenaran, jawaban, atau pengembangan ilmu pengetahuan. Terkait dengan ilmu pengetahuan, dapat dikemukakan tiga tujuan umum penelitian yaitu:

a. Tujuan Eksploratif, penelitian dilaksanakan untuk menemukan sesuatu (ilmu pengetahuan) yang baru dalam bidang tertentu. Ilmu yang diperoleh melalui penelitian betul-betul baru belum pernah diketahui sebelumnya.

b. Tujuan Verifikatif, penelitian dilaksanakan untuk menguji kebenaran dari sesuatu (ilmu pengetahuan) yang telah ada. Data penelitian yang diperoleh digunakan untuk membuktikan adanya keraguan terhadap infromasi atau ilmu pengetahuan tertentu.

c. Tujuan Pengembangan, penelitian dilaksanakan untuk mengembangkan sesuatu (ilmu pengetahuan) yang telah ada. Penelitian dilakukan untuk mengembangkan atau memperdalam ilmu pegetahuan yang telah ada.

\section{Motivasi}

Di kalangan para ahli muncul berbagai pendapat tentang motivasi. Masing-masing ahli memberikan pengertian tentang motivasi dengan titik berat yang berbeda-beda, sesuai dengan hasil penelitian yang mereka peroleh dan ilmu pengetahuan yang mereka pelajari. Meskipun demikian, ada juga semacam kesamaan pendapat yang dapat ditarik mengenai pengertian motivasi, yaitu: suatu tenaga atau faktor yang terdapat di dalam diri manusia, yang menimbulkan, mengarahkan dan mengorganisasikan tingkah lakunya. Sedangkan motif adalah suatu alasan atau dorongan yang menyebabkan seseorang berbuat sesuatu atau melakukan tindakan tertentu (Martin 1992: 9). Motivasi sendiri bukan merupakan suatu kekuatan yang netral, atau kekuatan yang kebal terhadap pengaruh faktor-faktor lain, misalnya cita-cita, kondisi lingkungan, keinginan untuk berprestasi dan kemampuan fisik. 
Dalam suatu motif umumnya terdapat dua unsur pokok, yaitu unsur dorongan atau kebutuhan dan unsur tujuan. Proses interaksi timbal balik antara kedua unsur di atas terjadi di dalam diri manusia, namun dapat dipengaruhi oleh hal-hal di luar diri manusia, misalnya keadaan cuaca, dan kondisi lingkungan. Oleh karena itu dapat saja terjadi perubahan motivasi dalam waktu yang relatif singkat, jika ternyata motivasi yang pertama mendapat hambatan atau tidak mungkin dipenuhi.

\section{Pengertian Motivasi}

Banyak istilah yang digunakan untuk menyebut motivasi (motivation) atau motif, yang antara lain adalah kebutuhan (need), desakan (urge), keinginan (wish) dan dorongan (drive). Kata Motivasi berasal dari kata Latin "Motive" yang berarti dorongan, daya penggerak atau kekuatan yang terdapat dalam diri seseorang yang menyebabkan seseorang itu bertindak atau berbuat. Selanjutnya diserap dalam bahasa Inggris motivation berarti pemberian motiv, penimbulan motiv atau hal yang menimbulkan dorongan atau keadaan yang menimbulkan dorongan. W.H. Haynes dan J.L Massie dalam Manulang (2001:165) mengatakan "motive is a something within the individual which incities him to action". Pengertian ini senada dengan pendapat The Liang Gie bahwa motive atau dorongan batin adalah suatu dorongan yang menjadi pangkal seseorang untuk melakukan sesuatu atau bekerja.

Kata motivasi atau motivation berarti pemberian motif, penimbulan motif atau keadaan yang menimbulkan dorongan. Motivasi dapat pula berarti sebagi faktor yang mendorong orang untuk bertindak dengan cara tertentu. Untuk lebih memahami apa motivasi, di bawah ini diuraikan pengertian dari motivasi yang dikemukakan para tokoh yang tahu tentang motivasi, di antaranya adalah sebagai berikut.

T. Hani Handoko (1984: 252) mengemukakan motivasi diartikan sebagai keadaan dalam pribadi seseorang yang mendorong keinginan individu untuk melakukan kegiatankegiatan tertentu guna mencapai tujuan. Pendapat ini didukung oleh Panji yang mengemukakan bahwa motivasi adalah kebutuhan yang mendorong perbuatan kearah suatu tujuan (Panji 2001: 34).

Menurut Hasibuan, motivasi mempersoalkan bagaimana caranya mendorong gairah kerja (dosen), agar mereka mau bekerja keras dengan memberikan semua kemampuan dan keterampilannya untuk mewujudkan tujuannya. ${ }^{10}$

Menurut Wahjosumidjo (1984:50) motivasi dapat diartikan sebagai suatu proses psikologi yang mencerminkan interaksi antara sikap, kebutuhan, persepsi, dan keputusan yang terjadi pada diri seseorang. Proses psikologi timbul diakibatkan oleh faktor di dalam

10 Hasibuan, S.P. Melayu, Manajemen Sumber Daya Manusia, (Jakarta: Bumi Aksara, 1985), hlm. 72 
diri seseorang itu sendiri yang disebut intrinsic dan extrinsic. Faktor di dalam diri seseorang bisa berupa kepribadian, sikap, pengalaman dan pendidikan, atau berbagai harapan, cita-cita yang menjangkau ke masa depan, sedang faktor dari luar diri dapat ditimbulkan oleh berbagi faktor-faktor lain yang sangat kompleks.

Wlodkowski (1985) menjelaskan motivasi sebagai suatu kondisi yang menyebabkan atau menimbulkan perilaku tertentu, memberikan arah dan ketahanan pada tingkah laku tersebut (behaviorisme). Ungkapan tersebut sesuai dengan pendapat I. Nyoman Sudita, dkk. (2000: 28) mengemukakan motivasi adalah faktor-faktor yang ada dalam diri seseorang yang menggerakkan, mengarahkan perilakunya untuk memenuhi tujuan tertentu. Sementara Ames (1984) mengemukakan bahwa motivasi adalah persepsi yang dimiliki seseorang mengenai dirinya sendiri dan lingkungannya (kognitif).

Cropley (1984) menjelaskan motivasi sebagai tujuan yang ingin dicapai melalui perilaku tertentu. Sementara Lefton mengartikan motivasi adalah kondisi internal yang spesifik dan mengarahkan prilaku seorang ke suatu tujuan (Lefton 1982: 143)

Dari beberapa pendapat tokoh di atas mengenai motivasi, dapat disimpulkan bahwa motivasi adalah suatu tenaga atau faktor yang terdapat di dalam diri manusia, yang menimbulkan, mengarahkan dan meng-organisasikan tingkah lakunya untuk memenuhi tujuan tertentu.

\section{Teori-teori tentang Motivasi}

\section{a. Teori Kognitif}

Manusia adalah mahluk rasional, demikian pandangan dasar para penganut teori kognitif ini. Berdasarkan rasionya manusia bebas memilih dan menentukan apa yang akan diperbuat, entah baik atau buruk. Tingkah laku manusia semata-mata ditentukan oleh kemampuan berfikirnya. Makin inteligen dan berpendidikan, otomotis seorang akan semakin baik perbuatan-perbuatanya, dan secara sadar pula melakukan perbuatanperbuatan yang memenuhi keinginan/kebutuhan tersebut.

Menurut teori ini tingkah laku seseorang digerakkan atau termotivasi oleh rasio. Setiap perbuatan yang akan dilakukannya sudah dipikirkan alasan-alasannya. Oleh karena itu setiap orang sungguh-sungguh bertanggung jawab atas segala perbuatannya. Di dalam teori ini juga diletakkan pentingnya fungsi kehendak. Bahkan fungsi kehendak disejajarkan dengan fungsi berfikir dan fungsi perasaan, sejauh fungsi berfikir dapat dipertanggung jawabkan.

\section{b. Teori Dorongan}

Teori dorongan menekankan pada hal yang mendorong terjadinya tingkah laku. Woodworth sebagai tokoh dari teori ini mengartikan dorongan sebagai suatu tenaga dari 
dalam diri kita yang menyebabkan kita berbuat sesuatu. Karena itu kata motif diberi arti dorongan yang menimbulkan dan mengarahkan serta mengorganisasikan tingkah laku manusia untuk mencapai tujuan tertentu.

Teori ini semakin popular dengan diakuinya oleh Psikologi Walter B Cannon pada tahun 1993 yang mengemukakan bahwa manusia seringkali terjadi ketidakseimbangan di dalam dirinya. Dorongan adalah salah satu usaha (otomatis) untuk dapat mengembalikan keadaan seimbang (Martin 1992: 23).

\section{c. Teori Harapan}

Vroom (1964) dalam kutipan Wayne dan Faules ${ }^{11}$ mengembangkan sebuah teori motivasi berdasarkan jenis pilihan yang dibuat orang untuk mencapai tujuan, alih-alih berdasarkan kebutuhan internal. Teori harapan (expectancy theory) memiliki tiga asumsi pokok:1) setiap individu percaya bahwa biar ia berperilaku dengan cara tertentu ia akan memperoleh hal tententu. Ini disebut harapan hasil (outcome expectancy). 2) setiap hasil mempunyai nilai, atau daya tarik bagi orang tertentu. Ini disebut valensi (valence), 3) setiap hasil berkaitan dengan suatu persepsi mengenai seberapa sulit mencapai hasil tersebut. Ini disebut harapan usaha (effort expectancy).

Dari teori harapan ini dapat disimpulkan bahwa: 1) suatu perilaku tertentu akan menghasilkan hasil tertentu, 2) hasil tertentu punya nilai positif baginya, 3) hasil tersebut dapat dicapai dengan usaha yang dilakukan seseorang. Jadi motivasi dalam teori harapan adalah keputusan untuk mencurahkan usaha.

Dari uraian teori motivasi di atas dapat disimpulkan bahwa secara garis besar teori motivasi dibedakan menjadi dua yaitu teori kepuasan (content theori) dan teori proses (process theori). Teori kepuasan berkaitan dengan faktor yang ada dalam diri seseorang yang memotivasinya, sedangkan teori proses berkaitan dengan bagaimana motivasi itu terjadi atau bagaimana perilaku itu digerakkan. Pengelompokkan kedua teori tersebut dapat dilihat dari tabel berikut ini:

\section{PENERAPAN TEORI PROSES DAN TEORI KEPUASAN}

\begin{tabular}{|l|l|l|}
\hline \multicolumn{1}{|c|}{ Jenis } & \multicolumn{1}{|c|}{ Karakteristik } & \multicolumn{1}{c|}{ Teori } \\
\hline Teori & Berkaitan dengan faktor-faktor & 1. Teori Hirarkhi kebutuhan \\
kepuasan & yang membangkitkan atau yang & 2. Teori ERG \\
& memulai prilaku & 3. Teori dua faktor \\
& & 4. Teori kebutuhan akan prestasi \\
\hline
\end{tabular}
125

11 Wayne dan Faules, Motivasi Peserta Didik Belajar, (Bandung: Sinar Baru Algesindo, 2000), hlm. 124- 


\begin{tabular}{|l|l|ll}
\hline Teori proses & $\begin{array}{l}\text { Berkaitan dengan bagaimana peri- } \\
\text { laku digerakkan, diarahkan, di- }\end{array}$ & $\begin{array}{l}\text { 1. Teori Pengharapan } \\
\text { dukung dan dihentikan }\end{array}$ & 3eori Keadilan \\
& & 4. Teori Penguatan
\end{tabular}

Sumber: I. Yoman Sudita (2000, h. 30)

Dari pendapat tersebut di atas dapat disimpulkan bahwa motivasi dosen dalam penelitian sangat erat hubungannya dengan motivasi berprestasi, sehingga sukses tidaknya kegiatan penelitian tersebut tergantung dari seberapa besar/kuat motivasi dosen dalam penelitian. Dengan istilah lain penelitian yang dikerjakan hasilnya akan baik jika dosen tersebut mempunyai motivasi yang tinggi untuk berprestasi.

\section{Analisis Diterminasi Rendahnya Dosen Penelitian}

Analisis determinansi adalah suatu proses yang dapat menghasilkan informasi teknis sebagai salah satu masukan bagi perumusan beberapa alternative pemecahan masalah yang didukung oleh informasi (Tilaar,1993: 43). Dalam kalimat analisis mengandung pendekatan normative dan deskriptif. Pendekatan normatif merupakan upaya dalam ilmu pengetahuan untuk menawarkan suatu norma, kaidah, atau resep yang dapat digunakan oleh pemakai dalam rangka memecahkan suatu masalah dalam hal ini adalah rendahnya motivasi dosen dalam penelitian. Tujuan pendekatan ini adalah untuk membantu mempermudah para pemakai hasil peneliti dalam menentukan atau memilih salah satu dari beberapa pilihan secara prosedur yang paling efesien dalam menangani atau memecahkan suatu masalah. Pendekatan normative untuk membantu para pengambil keputusan dalam bentuk pemikiran-pemikiran mengenai cara atau prosedur yang paling efisien dalam memecahkan suatu masalah yang dihadapi dosen dalam penelitian.

Dari pengertian di atas jika dikaitkan dengan permasalah analisis determinasi rendahnya motivasi dosen dalam penelitian, dapat penulis simpul bahwa analisis determinan adalah suatu proses yang sistematis, logis, ilmiah dalam menganalisisa penentu permasalahan yang dihadapai dosen (minimnya minat meneliti) serta bagaimana memberikan solusi permasalahan tersebut.

Dari analisis determinasi rendahnya dosen dalam penelitian diduga sebagai berikut:

\section{Minimnya Pelatihan dalam Penelitian}

Menurut Nitisemito (1994) "Pelatihan adalah suatu kegiatan yang bermaksud untuk dapat memperbaiki dan mengembangkan sikap, tingkah laku, keterampilan dan pengetahuan dari para seseorang yang sesuai dengan keinginan yang bersangkutan." Menurut Simamora (1997) "Pelatihan adalah proses sistematik pengubahan perilaku para karyawan dalam suatu arah guna meningkatkan tujuan-tujuan organisasional." 
Menurut Armstrong (1991) "Training is a planned process to modify attitude, knowledge or skill behavior through learning experience to achieve effective peformance in an activity or of activities."

Dari berbagai pendapat di atas maka peneliti dapat menarik kesimpulan bahwa pelatihan bukanlah merupakan suatu tujuan, tetapi merupakan suatu usaha untuk meningkatkan tanggung jawab terhadap profesi dan kompetensi yang dimiliki. Pelatihan merupakan proses keterampilan kerja timbal balik yang bersifat membantu, oleh karena itu dalam pelatihan seharusnya diciptakan suatu lingkungan di mana para dosen dapat memperoleh atau mempelajari sikap, kemampuan, keahlian, pengetahuan dan perilaku yang spesifik yang berkaitan dengan pekerjaan, sehingga dapat memotivasi mereka untuk mengadakan penelitian.

\section{Seminar dalam Penelitian}

Kata seminar berasal dari kata Latin semin yang berarti "benih". Jadi, seminar berarti "tempat benih-benih kebijaksanaan". Seminar merupakan pertemuan ilmiah yang dengan sistematis mempelajari suatu topik khusus di bawah pimpinan seorang ahli dan berwenang dalam bidang tersebut.

Seminar merupakan suatu pertemuan atau persidangan untuk membahas suatu masalah di bawah pimpinan guru besar atau seseorang ahli. Pertemuan atau persidangan dalam seminar biasanya menampilkan satu atau beberapa pembicaraan dengan makalah atau kertas kerja masing-masing. Seminar biasanya diadakan untuk membahas suatu masalah secara ilmiah. Yang berpartisipasi pun orang yang ahli dalam bidangnya.

Seminar tentang trik-trik mendapatkan penelitian, tentu dihadiri oleh para pakar bidang peneliti. Sementara itu, peserta berperan untuk menyampaikan pertanyaan, ulasan, dan pembahasan sehingga menghasilkan pemahaman tentang suatu masalah.

Seminar hanya membahas cara pemecahan masalah, karena inti dari sebuah seminar merupakan sebuah diskusi, laporan seminar pun merupakan laporan hasil diskusi. Oleh karena itu, laporan seminar hendaknya berisi hal-hal yang penting saja. Seminar bukan diadakan untuk menetapkan suatu keputusan terhadap masalah yang dibicarakan. Seminar hanya membahas cara pemecahan masalah. Seminar bisa dilakukan di ruang perpustakaan, ruang sidang bahkan ruang kelas juga bisa menyelenggarakan seminar. Dalam hal ini seminar yang penting mencoba membahas suatu masalah dengan argumen-argumen yang logis, tidak emosional dan para pembicaranya pun menggunakan gagasan, pendapat, tanggapan, pembahasan secara ilmiah pula.

\section{Diskusi Penelitian}

Kata diskusi berasal dari bahas Latin discutio atau discusum yang berarti bertukar pikiran. Dalam bahasa Inggris digunakan kata discussion yang berarti perundingan atau pembicaraan. 
Dari segi istilah, diskusi berarti perundingan/bertukar pikiran tentang suatu masalah: untuk memahami, menemukan sebab terjadinya masalah, dan mencari jalan keluarnya. Diskusi ini dapat dilakukan oleh dua-tiga orang, puluhan, dan bahkan ratusan orang. Diskusi adalah sebuah proses tukar menukar informasi, pendapat, dan unsur unsur pengalaman secara teratur dengan maksud untuk mendapatkan pengertian bersama yang lebih jelas, lebih teliti tentang sesuatu atau untuk mempersiapkan dan merampungkan kesimpulan/pernyataan/keputusan. Di dalam diskusi selalu muncul perdebatan. Debat ialah adu argumentasi, adu paham dan kemampuan persuasi untuk memenangkan pemikiran/paham seseorang.

\section{Simposium Penelitian}

Simposium merupakan pertemuan terbuka dengan beberapa pembicara yang menyampaikan ceramah pendek mengenai aspek yang berbeda tetapi saling berkaitan tentang suatu masalah. Simposium dipimpin oleh seorang ketua yang bertugas mengatur jalannya diskusi. Pendengar bertanya dan para ahli menjawab.

\section{Anggaran}

Banget merupakan rencana operasional yang dinyatakan secara kuantitatif dalam bentuk satuan uang yang digunakan sebagai pedoman dalam melaksanakan kegiatankegiatan yang dalam hal ini adalah kegiatan penelitian dalam kurung waktu tertentu. Oleh karena itu dalam anggaran tergambar kegiatan-kegiatan yang yang akan dilaksanakan oleh peneliti

Sebagaimana kita katahui bahwa anggaran penelitian dalam pendidikan masih dianggap kecil yang diberikan. Dana merupakan stimulus tersendiri bagi peneliti, karena dengan dana yang cukup besar dapat menjadi motivasi bagi peneliti untuk berkompetisi.[] 


\section{DAFTAR PUSTAKA}

Bogdan, Robert. C. dan Biklen, Sari Knopp, Riset Kualitatif untuk Pendidikan: Pengantar Teori dan Metode, alih bahasa: Munandir, Jakarta: Ditjen Dikti Depdikbud, 1990.

Brannen, Mixing Methods Qualitative and Quantitative Research, terj. Kurde, Yogyakarta: Pustaka Pelajar, 1997.

Danim, Sudarwan, Metode Penelitian untuk Ilmu-Ilmu Perilaku, Jakarta: Bumi Aksara, 200

Danim, Sudarwan, Menjadi Peneliti Kualitatif, Bandung: Pustaka Setia, 2002.

Dedi Supriyadi dan Tilaar, Analisis Kebijakan Publik Suatu Pengantar. Bandung: Rosdakarya, 1993.

Ekosusilo, Madyo, "Desain Penelitian Kualitatif”, makalah disajikan dalam Penataran Metodologi Penelitian Kualitatif yang diselenggarakan oleh Dinas P \& K Kabupaten Batang pada tanggal 15 Oktober 2001.

Faisal, Singgih, Penelitian Kualitatif, Malang: YA3, 1990.

Gitosudarmo, Indriyo, Sudita, dan I Nyoman, Perilaku Keorganisasian, Yogyakarta: BPFE, 2000.

Muhadjir, Noeng, Metodologi Penelitian Kualitatif, Yogyakarta: Rake Sarasin, 1989.

Hasibuan, S.P. Melayu, Manajemen Sumber Daya Manusia, Jakarta: Bumi Aksara, 1985.

Lincoln, Y.S., \& Guba, E.G., Naturalistic Inquiry, Beverly Hill: Sage Publication Inc., 1985.

Nasution, S., Metode Penelitian Naturalistik-Kualitatif, Bandung: Tarsito, 1996.

Sarwono, Jonathan, Penuntun Penelitian Praktis, Bandung: Universitas Kristen Maranatha, 1995.

Sudjana, N. dan Ibrahim, R., Penelitian dan Penilaian Pendidikan, Bandung: Sinar Baru Algesindo, 2001.

Sudjana, Nana, Tuntunan Penyusunan Karya Ilmiah, Bandung: Sinar Baru Algesindo, 2001.

Sugiyono, Metode Penelitian Pendidikan; Pendekatan Kuantitatif, Kualitatif dan R\&D, Bandung: Alfabeta, 2007.

Sukardi, Metodologi Penelitian Pendidikan (Kompetensi dan Praktiknya), Jakarta: Bumi Aksara, 2003.

Wayne dan Faules, Motivasi Peserta Didik Belajar, Bandung: Sinar Baru Algesindo, 2000. 